\title{
Irrigation canals in Melo creek basin (Rio Espera and Capela Nova municipalities, Minas Gerais, Brazil): habitats to Biomphalaria (Gastropoda: Planorbidae) and potential spread of schistosomiasis
}

\author{
M. G. P. Leite ${ }^{a *}$, E. C. Pimenta ${ }^{a}$, M. A. G. Fujaco ${ }^{a}$ and E. M. Eskinazi-Sant'Anna ${ }^{a, b}$ \\ aPrograma de Pós-graduação em Evolução Crustal e Recursos Naturais, Departamento de Geologia, \\ Universidade Federal de Ouro Preto - UFOP, Campus Morro do Cruzeiro, CEP 35400-000, Ouro Preto, MG, Brazil \\ bLaboratório de Ecologia Aquática, Evolução e Conservação, Universidade Federal de Ouro Preto - UFOP, \\ Campus Morro do Cruzeiro, CEP 35400-000, Ouro Preto, MG, Brazil \\ *e-mail: mgpleite@gmail.com
}

Received: October 30, 2014 - Accepted: June 29, 2015 - Distributed: August 31, 2016

(With 2 figures)

\begin{abstract}
This study analyzed the presence of Biomphalaria in Melo creek basin, Minas Gerais state, and its relationship to irrigation canals. Seventeen of these canals were used to determine a limnological, morphological and hydrological characterization during an annual seasonal cycle. Biomphalaria samples were sent to René Rachou Research Center/FIOCRUZ for identification and parasitological examination. Six canals were identified as breeding areas for mollusks and in one of them it was registered the coexistence of B. tenagophila (first report to this basin) and B. glabrata species. Results indicated that the low flow rate and speed of water flow were the main characteristics that contributed to this specific growth of the mollusks in the area. These hydraulic characteristics were created due to anthropogenic action through the canalization of lotic areas in Melo creek, which allowed ideal ecological conditions to Biomphalaria outbreak. The results emphasize the need of adequate handling and constant monitoring of the hydrographic basin, subject to inadequate phytosanitary conditions, aiming to prevent the occurrence and propagation of schistosomiasis.
\end{abstract}

Keywords: mollusk, limnology, hydrology, watershed management, Brazil.

\author{
Canais de irrigação na bacia do ribeirão do Melo \\ (Municípios de Rio Espera e Capela Nova, Minas Gerais, Brasil): \\ habitats para a proliferação de Biomphalaria (Gastropoda: Planorbidae) e \\ potencial disseminação da esquistossomose
}

\begin{abstract}
Resumo
Neste estudo avaliou-se a presença de espécies de Biomphalaria na bacia do Ribeirão do Melo, municípios de Rio Espera e Capela Nova, sudeste do estado de Minas Gerais, e sua relação com os canais de irrigação presentes na região. Em 17 desses canais foi realizada uma caracterização limnológica, morfológica e hidrológica durante um ciclo sazonal anual. Espécimes de Biomphalaria foram coletados e encaminhados ao Centro de Pesquisas René Rachou/FIOCRUZ (Belo Horizonte, MG) para identificação e exame parasitológico. Dos 17 canais estudados, foram identificados seis como criadouros do caramujo, sendo que em um dos canais coexistiam as espécies $B$. tenagophila (primeiro registro para a bacia) e $B$. glabrata. Os resultados indicaram que a baixa vazão e a velocidade do fluxo foram os fatores que contribuíram para a ocorrência pontual dos caramujos na bacia. Estas características hidrológicas foram modificadas por ação antropogênica, através da canalização de trechos lóticos do ribeirão do Melo. Os resultados destacam a necessidade do manejo adequado e monitoramento constante da bacia hidrográfica, sujeita a condições sanitárias inadequadas, como forma de prevenção da ocorrência e propagação da esquistossomose.
\end{abstract}

Palavras-chave: molusco, limnologia, hidrologia, manejo de bacias, Brasil.

\section{Introduction}

Schistosomiasis is pointed out as the most important global tropical disease by many authors (Coura and Amaral, 2004; Steinmann et al., 2006; Carvalho et al., 2008; Feasey et al., 2010; Gray et al., 2010; Rollinson et al., 2013; Martins-
Melo et al., 2014). Data from World Health Organization (WHO, 2012) reveal that more than 249 million people in 78 countries are infected with Schistosoma mansoni (Sambon, 1907); 7.1 million in the Americas, 95\% of which 
in Brazil (Favre et al., 2012; Martins-Melo et al., 2014). The disease had been catalogued by the Global Plan as one the Neglected Tropical Diseases, and is considered by the World Health Organization (WHO) to be the second most socioeconomically devastating parasitic disease, next to malaria (WHO, 2012). Martins-Melo et al. (2014) pointed out that from 2000 to 2012 in Brazil, 8756 deaths were related to schistosomiasis $(0,07 \%)$, representing an annual average mortality of 0.49 deaths/100,000 inhabitants.

As an attempt to define risk areas and minimize the propagation of schistosomiasis, several studies have been held in endemic areas, with the intention of finding the main factors that can explain the increase of Biomphalaria species populations. According to Brazilian Health Department (Brasil, 2010), Minas Gerais is one of the Brazilian states with a large endemic area for schistosomiasis, where the higher number of infections has been found in the Northeast and East regions (Kloos et al., 2001; Massara et al., 2008), which comprehend Mata Zone (Lambertucci et al., 1987; Carvalho et al., 1989; Guimarães et al., 2008; Martins-Melo et al., 2014).

Biomphalaria is a genus of air-breathing freshwater snails, aquatic pulmonate gastropod mollusks in Planorbidae, which species B. glabrata (Say, 1818), B. straminea (Dunker, 1848) and B. tenagophila (d'Orbigny, 1835) show irrefutable epidemiological importance, because, according to Passos et al. (1998), they are the only ones capable of being naturally infected by the trematode Schistosoma mansoni. Even though Biomphalaria species can be found in various lotic and lentic environments, artificial canals offer a more adequate habitat for these vectors species (Southgate, 1997; Jobin, 1999; Steinmann et al., 2006; Rollinson, 2009; Rollinson et al., 2013), due to organic matter accumulation and micro-habitats provided.

Irrigation canals and dams are usually built to guarantee the stability of agriculture-related activities. It is a disseminated practice in developing countries, especially those located in tropical areas (Maszle et al., 1998; Rollinson et al., 2013). Several studies have shown a positive relationship between these irrigation structures and the distribution of Biomphalaria species in Africa (Wurapa et al., 1989; Steinmann et al., 2006), Asia (Maszle et al., 1998) and Middle East - Saudi Arabia (Sinha and Lambourne, 1987). In Brazil, the importance of these artificial breeding areas has also been verified in some studies (Coimbra Júnior et al., 1984; Coutinho et al., 1992; Kloetzel et al., 1994; Kloos et al., 2004). According to Pepe (2006), from all Biomphalaria tenagophila guaibensis (Paraense, 1984), Biomphalaria peregrina (d'Orbigny, 1835) and Biomphalaria oligoza (Paraense, 1975) samples collected in 15 different small towns, in Rio Grande do Sul state, $87 \%$ were founded in irrigation canals.

In the small watershed of Melo creek, several irrigation canals were manually built in order to satisfy the hydraulic needs for subsistence cultures, mainly of rice, beans and sugar cane. Apart from the inadequate use of the hydraulic resources, the Melo creek watershed faces other problems, like the precarious state of the sanitary system, disorderly and accelerated deforestation, lack of public health policies and almost absence of limnological studies in the area. All these factors contribute to the propagation of schistosomiasis, which, according to the National Health Foundation (Brasil, 2008) is endemic in Melo creek basin. In the region, more than 100 cases of the disease were reported between 2011 and 2012 .

The understanding of schistosomiasis intermediate hosts distribution in Melo creek basin, focusing mainly in the role of irrigation canals that may serve as breeding areas for these organisms, is very important since problems originated from the prevalence of the disease contributes to aggravate the social status of the municipality. The present study is the first initiative accomplished in Melo creek watershed with the main goal of evaluating the effect of hydrodynamic and limnological features of the irrigation canals in the occurrence and dissemination of Biomphalaria species. We hope the results help to identify potential transmission foci, contributing to preventive sanitary actions. In addition, we aimed our results can contribute to implement local environmental planning concerning use and occupation of Melo creek watershed.

\section{Material and Methods}

\subsection{Study area}

Melo creek watershed is located in the state of Minas Gerais, approximately $200 \mathrm{~km}$ from Belo Horizonte (Figure 1), in the Forest Zone, a micro region of Viçosa region. The watershed has 9.076 hectares, $62 \%$ of those belonging to the Rio Espera and $38 \%$ to Capela Nova municipalities. The annual precipitation average is very high $(1900 \mathrm{~mm})$, with humid summers and dry winters. The basin is located inside the Atlantic Forest bioma, but due to the high level of anthropization, very few areas preserve the original vegetation.

The most part of domestic sewage generated by rural properties in the watershed is thrown directly into the streams. Documents reported 6.767 positive cases of the disease from January 1995 to March 2009 in Capela Nova and Rio Espera municipalities (Brasil, 2010).

Limnological measurements, water and mollusks samples were collected in 17 spots along the basin (Figure 1), in September 2008, March 2009, July 2009 and September 2009. The sampling points were defined for representing the main streams and the irrigation canal in use in the watershed. With the intention of characterizing the morphology and determine the water discharge of the streams and canals, width, depth and speed of the transversal section flow were measured in each sampled spot. Water speed measurements were taken using a micro hydraulic windlass FP201 Global Flow Probe.

The temperature $\left({ }^{\circ} \mathrm{C}\right)$, electrical conductivity $\left(\mu \mathrm{S} . \mathrm{cm}^{-1}\right)$, total dissolved solids (mg. $\mathrm{L}^{-1}$ ), oxi-reduction potential (Eh) and $\mathrm{pH}$ were obtained using a portable multiparameter (Myron L Company, model 6P). Water turbidity (NTU) was determined using a portable Microprocessor Turbidity Meter - HI 93703 (HANNA Instruments), and dissolved 


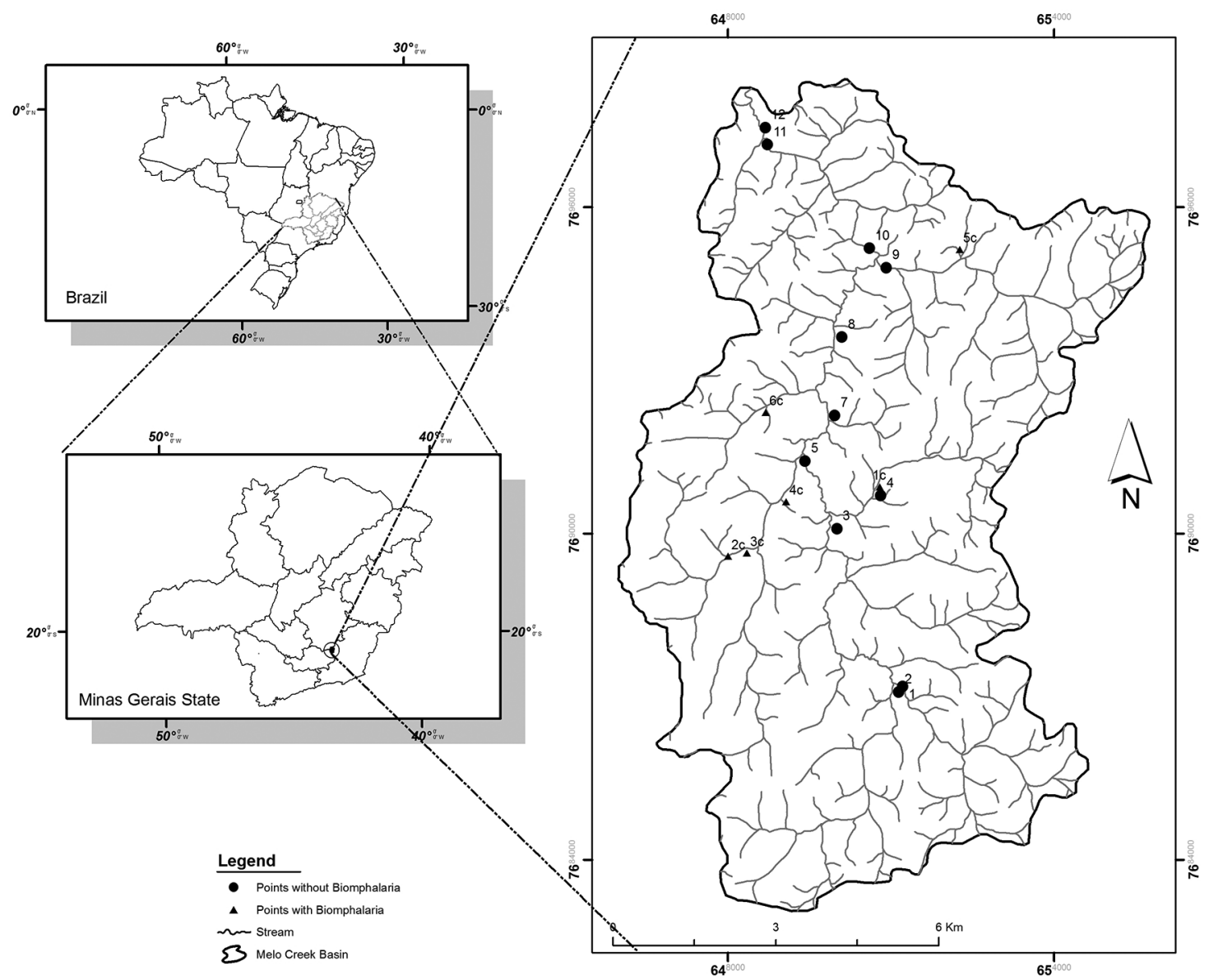

Figure 1. Map showing the localization of Melo creek basin in the state of Minas Gerais (Brazil) and monitored points. Sampling points $6,13,14,15,16$ and 17 with snail occurrence.

oxygen (mg. $\left.\mathrm{L}^{-1}\right)$ was measured with an oximeter DM-4D Digimed. All equipments were previously calibrated in laboratory.

The sampling of snails was based on the technique recommended by Paraense (1970) described by Souza and Lima (1997), which consists of scraping the underwater vegetation with a capturing net, alongside and deep in the breeding area for 15 minutes. All collected snails were transferred to glass or plastic recipients filled with water from the sampling point, numbered and sent to Laboratório de Helmintologia e Malacologia Médica of the Centro de Pesquisas René Rachou/FIOCRUZ located in Belo Horizonte (MG), for identification and tests for Schistosoma mansoni infestation. The tests for cercarial infestation were carried out according to standardized methods of the Centro de Pesquisas René Rachou/FIOCRUZ.

The results were statistically analyzed with Minitab ${ }^{\circledR}$ 16 program, where a basic statistic study was performed (average of standard deviation for density and limnological parameters determination). The difference between the averages was analyzed with the T-student test for independent samples. To verify the effect of flow and speed of water over the density of Biomphalaria individuals, a Pearson correlation analysis was performed.

\section{Results}

In Melo creek basin, six Biomphalaria breeding areas were found in sample points: $6,13,14,15,16$ and 17 , which are part of irrigation systems, created inside properties in order to irrigate cultures and provide water for cattle.

Figure 2 and Table 1 show the data of morphological and hydraulic characteristics for each location and for point with and without mollusks. Figure 2a shows that the width of the canals didn't present a significant difference between the breeding areas $(P>0.05)$ and the remaining locations, with the exception of sampling points 10 and 12 , where the width was significantly larger than the other locations $(P=0.02)$. Even though the breeding areas were very shallow, with depths ranging from 0.1 to $0.9 \mathrm{~m}$, this parameter did not differ statistically from the other sampling points (Figure 2b).

Differences begin to emerge when the average canal speed is analyzed (Figure 2c). Clearly, the breeding areas present the lowest flow speeds, but only locations 

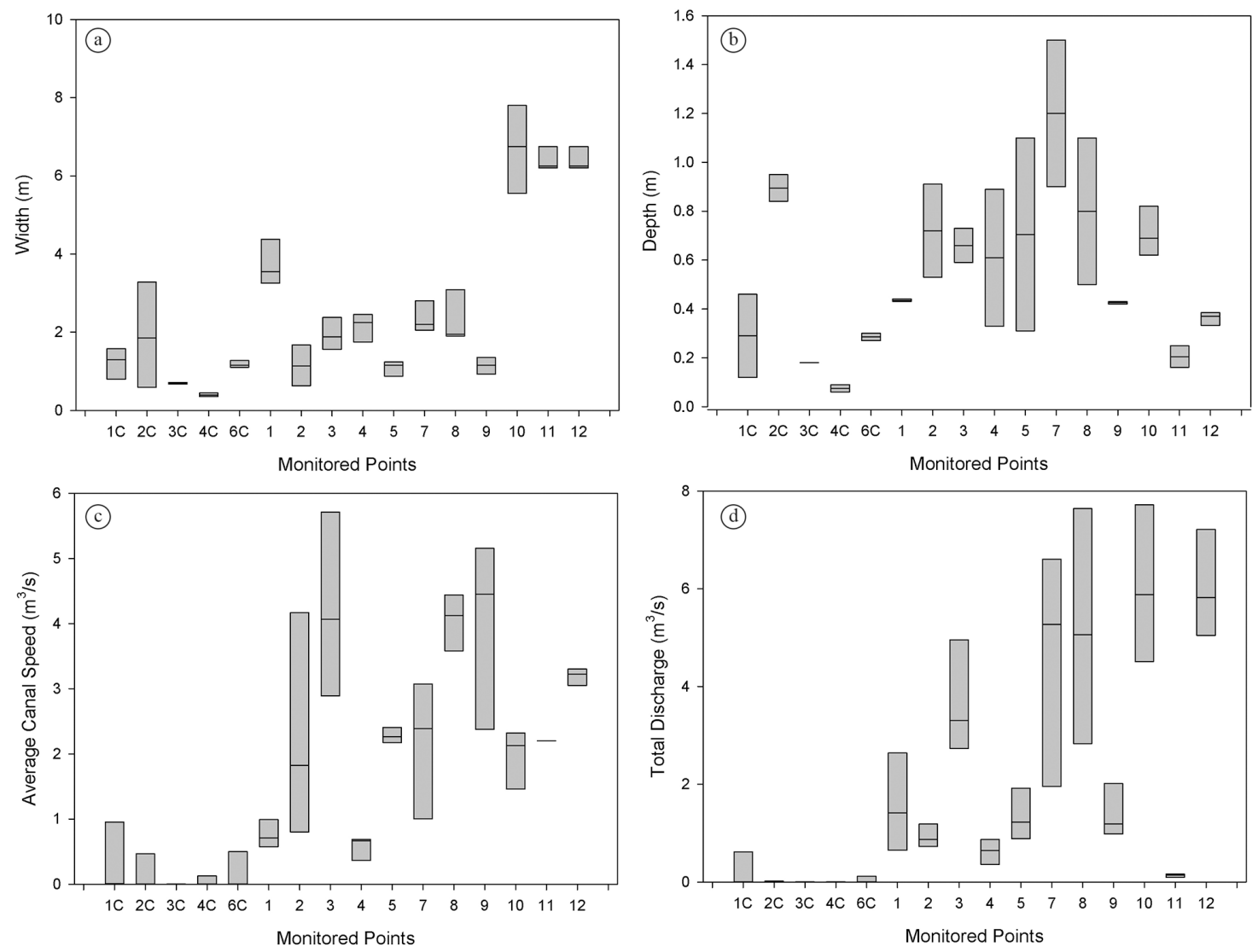

Figure 2. Morphological and hydraulic aspects of the sampling points in Melo creek basin, Minas Gerais state, Brazil. (a) Width (m); (b) Depth (m); (c) Average canal speed ( $\left.\mathrm{m}^{3} / \mathrm{s}\right)$ and (d) Total discharge $\left(\mathrm{m}^{3} / \mathrm{s}\right)$. Points 6, 13, 14, 15 and 16 with occurrence of Biomphalaria species.

Table 1. Limnological parameters of the sampling points (minimum, average and maximum values), with snail occurrence (SPWIS) and without snail occurrence (SPWUS) in Melo creek watershed, Minas Gerais state, Brazil.

\begin{tabular}{|c|c|c|c|c|c|c|}
\hline \multirow{2}{*}{ Parameters } & \multicolumn{3}{|c|}{ SPWIS } & \multicolumn{3}{|c|}{ SPWUS } \\
\hline & Minimum & Average & Maximum & Minimum & Average & Maximum \\
\hline Dissolved Oxygen (mg/L) & 1.56 & 5.67 & 9.79 & 3.02 & 6.14 & 8.55 \\
\hline pH & 5.49 & 6.5 & 7.11 & 4.89 & 6.6 & 7.6 \\
\hline Turbidity (NTU) & 0.0 & 13.2 & 55.0 & 0.0 & 5.7 & 43.57 \\
\hline Temperature $\left({ }^{\circ} \mathrm{C}\right)$ & 14.2 & 21.7 & 27 & 14.4 & 21.1 & 26.4 \\
\hline Eh $(\mu \mathrm{V})$ & 3 & 117.6 & 255 & 19 & 109.31 & 253 \\
\hline Conductivity $(\mu \mathrm{mS} / \mathrm{cm})$ & 26.81 & 48.7 & 106.3 & 14.67 & 37.64 & 114.8 \\
\hline Length (m) & 0.34 & 0.85 & 1.60 & 0.32 & 2.67 & 7.80 \\
\hline Depth (m) & 0.06 & 0.34 & 0.95 & 0.16 & 0.37 & 0.62 \\
\hline Area $\left(m^{2}\right)$ & 0.01 & 0.37 & 2.32 & 0.05 & 1.27 & 3.82 \\
\hline Mean velocity $(\mathrm{m} / \mathrm{s})$ & 0.001 & 0.08 & 0.66 & 0.27 & 2.52 & 6.11 \\
\hline Discharge $\left(\mathrm{m}^{3} / \mathbf{s}\right)$ & 0.00001 & 0.007 & 0.08 & 0.09 & 2.86 & 8.37 \\
\hline
\end{tabular}

13 and 16 presented statistic similarity (Test $\mathrm{t} P=0,000)$. However, the characteristic that made those breeding areas distinct when compared to the remaining sampled points, was irrefutably the total flow (Figure 2d), because these parameter gathers the morphological and hydraulic characteristics of the canal. As shown in Figure 2d, the breeding areas possess inferior water discharges $(\mathrm{P}=0,000)$. Only the flow on location 11 was similar to that measured in breeding areas, but this canal shows a higher speed (twice the mean speed measured in sampling points with snail occurrence); in other words, its reduced discharge is due to its small dimensions (Table 1, Figures 2a and 2b) 
but the water flow speed inhibits mollusks occurrence. A negative correlation between density of Biomphalaria and the hydrodynamic characteristics of the samples $\left(r^{2}\right.$ discharge $=-0.27 ; P=0.00 ; \mathrm{r}^{2}$ speed $\left.=-0.32 ; P=0.00\right)$ was observed, indicating the control of hydraulic parameters in the potential spatial distribution of Biomphalaria in the basin.

Physical-chemical characteristics of the water are represented in Table 1. Limnological characteristics did not displayed significant difference that allowed distinction between breeding areas and the other monitored points $(P>0.05)$. The water with Biomphalaria specimens proved to be well oxygenated, with slightly acid characteristics and higher mean values of turbidity and electric conductivity (Table 1).

Taxonomic analysis of the collected mollusks showed the occurrence of two species: B. tenagophila and B. glabrata, the latter being found in all six points identified as areas of Biomphalaria occurrence. Only in location 15, the two species coexist. It is important to highlight that this was the first time that B. tenagophila specimens were described in the watershed. All samples collected presented negative results for Schistosoma mansoni infestation.

\section{Discussion}

Even though all 17 monitored locations have similar physical-chemical characteristics and no morphological differences, their hydraulic characteristics allow the distinction between the breeding areas from the remaining sampled points. The snails are concentrated in irrigation canals, that offer slow speeds and low discharges, where they can fixate more easily and find food resources (Paraense, 1970; Ramos et al., 1969; Muniz, 2007).

Vegetation in environments with these hydraulic characteristics is normally composed of macrophytes, which create perfect microhabitats and also offer protection for mollusks eggs, which are deposited underneath the leafs (Ramos et al., 1969; Muniz, 2007; Pieri, 2007).

Regarding the tolerance facing the main physical characteristics of the water, all 17 sampled locations present satisfactory results in relation to mollusk adaptation. In other words, Melo creek watershed offers the necessary conditions for the successful spreading of these species as long as the speed of the canals and the discharge remain low. This is exactly how the irrigation canals are defined, what contributes to the increase of intermediate host distribution and as a consequence of that, creates potential future outbreak of the disease.

The presence of breeding areas in canals has been described (Coimbra Júnior et al., 1984; Coutinho et al., 1992; Kloetzel et al., 1994; Kloos et al., 2001, 2004), showing that, in fact, these environments deserve our attention in order to control the distribution of the snails potentially intermediate hosts of schistosomiasis. On the other hand, it is a fact that irrigation canals contribute to agricultural production, especially in developing countries rural areas. The mechanization of agriculture areas can solve this problem since it creates a distance between farmers and the water used in the irrigation process, therefore interrupting the cycle of the disease (Martins and Barreto, 2003). However, this approach can be considered an expensive measure for a population that survives on a very low budget like it's the case in Melo basin. Another option would be to keep the canals in open air and distribute water through closed pipes, which would increase the speed and water flow, contributing to reduce the proliferation of vegetation; this could difficult the outbreak of snails by reducing habitat and food availability.

As the control of schistosomiasis is a public health need, all governments in endemic areas should be encouraged to undertake control interventions, including environmental education

(Chitsulo et al., 2000; Boelee and Laamrani, 2004). An intensified effort to educating people on the risk of Schistosoma mansoni infection and transmission is an initial, but decisive step towards a more effective local control of Biomphalaria occurrence.

\section{Conclusions}

It is known that anthropic interference is directly connected with the spreading of mollusks throughout a river basin. In face of the results obtained, it becomes clear that the manufacturing of irrigation canals in Melo creek watershed contributes to the spring and survival of schistosomiasis, since this action creates the ideal habitat for intermediate hosts of the disease. If control policies continue to be nonexistent, the mollusks will spread throughout the whole watershed. Even with negative results for Schistosoma mansoni, the reports on Biomphalaria species occurrence alert about the possibility of a schistosomiasis outbreak in that area.

Apart from specific environmental conditions and the installment of a parasitic cycle that are made possible by the irrigation canals, there are also factors that contribute to the recurrence of the disease, such as presence of domestic sewage in water bodies, waterfalls and other sections of the river that are used for recreation, and a high level of individuals infected in the region. In order to eliminate or at least reduce the problem, the participation of the population is indispensable, as only they can control the creation of new irrigation canals and to perform the cleanliness of the existing ones. Furthermore, government authorities need implement sanitary and environmental educational programs associated with the construction of septic tanks.

\section{Acknowledgements}

The authors would like to acknowledge FAPEMIG for financial support (CRA-APQ-03447-09_50507). Graduate fellowships were granted to ECP from the Coordenação de Aperfeiçoamento de Pessoal de Nível Superior (CAPES). We would like to specially thank the Laboratório de Helmintologia e Malacologia Médica do Centro de Pesquisas René Rachou/ FIOCRUZ for analysis of Biomphalaria 
snails. We would also like to thank Juliana S. Q. de Oliveira e Ana C. C. Trindade from Programa de Educação Tutorial (PET - Geology Departament of UFOP) for their help in the laboratory activities. We are also very grateful to inhabitants from Rio Espera and Capela Nova municipalities that contributed to the conclusion of this study. MGPL and EMES are researchers of the Brazilian National Council for Scientific and Technological Development (CNPq). We thank the reviewer for constructive comments to the manuscript.

\section{References}

BOELEE, E. and LAAMRANI, H., 2004. Environmental control of schistosomiasis through community participation in a Moroccan Oasis. Tropical Medicine \& International Health, vol. 9, no. 9, pp. 997-1004. http://dx.doi.org/10.1111/j.1365-3156.2004.01301.x. PMid:15361113.

BRASIL. Fundação Nacional de Saúde - FUNASA, 2008. Levantamento epidemiológico de 1996 a 2004: resumo das atividades de coproscopia e tratamento por localidade do Estado de Minas Gerais. Belo Horizonte.

BRASIL. Ministério do Meio Ambiente - MMA, 2010 [viewed 21 June 2014]. Vigilância epidemiológica. Tabela de casos confirmados de Esquistossomose: 1995 a 2007 [online]. Brasília. Available from: http://portal.saude.gov.br/ portal/arquivos/pdf/ serie_historica_esquitossomose.pdf

CARVALHO, O.S., COELHO, P.M.Z. and LENZI, H.L., 2008. Schistosoma mansoni e esquistossomose: uma visão multidisciplinar. 1th ed. Rio de Janeiro: Fiocruz. 1124 p.

CARVALHO, O.S., MASSARA, C.L., ROCHA, R.S. and KATZ, N., 1989. Esquistossomose mansoni no sudoeste do estado de Minas Gerais (Brasil). Revista de Saúde Pública, vol. 23, no. 4, pp. 341-344. http://dx.doi.org/10.1590/S0034-89101989000400010. PMid:2517153.

CHITSULO, L., ENGELS, D., MONTRESOR, A. and SAVIOLI, L., 2000. The global status of schistosomiasis and its control. Acta Tropica, vol. 77, no. 1, pp. 41-51. http://dx.doi.org/10.1016/ S0001-706X(00)00122-4. PMid:10996119.

COIMBRA JÚNIOR, C.E., SANTOS, R.V. and SMANIO NETO, L., 1984. Endemic potential of shistosomiasis for the State of Rondônia, Brazil. Revista de Saúde Pública, vol. 18, no. 6, pp. 510-515. PMid:6536119.

COURA, J.R. and AMARAL, R.S., 2004. Epidemiological and control aspects of schistosomiases in Brazilian endemic areas. Memórias do Instituto Oswaldo Cruz, vol. 99, no. 5, suppl. 1, pp. 13-19. PMid:15486629.

COUTINHO, A.D., SILVA, M.L. and GONÇALVES, J.F., 1992. Epidemiological study on mansoni schistosomiasis in irrigation areas of Northeastern Brazil. Cadernos de Saúde Pública, vol. 8, no. 3, pp. 302-310. http://dx.doi.org/10.1590/S0102311X1992000300009.

FAVRE, T.C., COUTINHO, C.F.S., COSTA, K.G., GALVAO, A.F., PEREIRA, A.P.B., BECK, L., CRUZ, O.G. and PIERI, S., 2012. Directives for schistosomiasis control in endemic areas of Brazil. In: M.B. ROKNI, ed. Schistosomiasis. Croatia: InTech Publisher, pp. 104-118.
FEASEY, N., WANSBROUGH-JONES, M., MABEY, D.C. and SOLOMON, A.W., 2010. Neglected tropical diseases. British Medical Bulletin, vol. 93, no. 1, pp. 179-200. http://dx.doi. org/10.1093/bmb/ldp046. PMid:20007668.

GRAY, D.J., MCMANUS, D.P., LI, Y., WILLIAMS, G.M., BERGQUIST, R. and ROSS, A.G., 2010. Schistosomiasis elimination: lessons from the past guide the future. The Lancet Infectious Diseases, vol. 10, no. 10, pp. 733-736. http://dx.doi. org/10.1016/S1473-3099(10)70099-2. PMid:20705513.

GUIMARÃES, R.J.P.S., FREITAS, C.C., DUTRA, L.V., MOURA, A.C.M., AMARAL, R.S., DRUMMOND, S.C., SCHOLTE, R.G.C. and CARVALHO, O.S., 2008. Schistosomiasis risk estimation in Minas Gerais State, Brazil, using environmental data and GIS techniques. Acta Tropica, vol. 108, no. 2-3, pp. 234-241. http:// dx.doi.org/10.1016/j.actatropica.2008.07.001. PMid:18692017.

JOBIN, W.R., 1999. Dams and disease: ecological design and health impacts of large dams, canals, and irrigation systems. London: E\&FN Spon. 600 p.

KLOETZEL, K., CHIEFFI, P.P. and CARRILHO, F.J., 1994. Environmental intervention as a tool for control of schistosomiasis: suggestions from a field study in Northeast Brazil. Cadernos de Saúde Pública, vol. 10, suppl. 2, pp. 337-344. http://dx.doi. org/10.1590/S0102-311X1994000800011. PMid:15042223.

KLOOS, H., PASSOS, L.K.J., LOVERDE, P., OLIVEIRA, R.C. and GAZZINELLI, A., 2004. Distribution and Schistosoma mansoni infection of Biomphalaria glabrata in different habitats in a rural area in the Jequitinhonha Valley, Minas Gerais, Brazil: environmental and epidemiological aspects. Memórias do Instituto Oswaldo Cruz, vol. 99, no. 7, pp. 673-681. http://dx.doi.org/10.1590/ S0074-02762004000700002. PMid:15654420.

KLOOS, H., SOUZA, C., GAZZINELLI, A., SOARES FILHO, B.S., TEMBA, P.C., BETHONY, J., PAGE, K., GRZYWACZ, C., LEWIS, F., MINCHELLA, D., LOVERDE, P. and OLIVEIRA, R.C., 2001. The distribution of Biomphalaria spp. in different habitats in relation to physical, biological, water contact and cognitive factors in a rural area in Minas Gerais, Brazil. Memórias do Instituto Oswaldo Cruz, vol. 96, suppl., pp. 57-66. http:// dx.doi.org/10.1590/S0074-02762001000900008. PMid:11586427.

LAMBERTUCCI, J.R., ROCHA, R.S., CARVALHO, O.S. and KATZ, N., 1987. A esquistossomose mansoni em Minas Gerais. Revista da Sociedade Brasileira de Medicina Tropical, vol. 20, no. 1, pp. 47-52. http://dx.doi.org/10.1590/S0037-86821987000100010. PMid:3149415.

MARTINS JUNIOR, J.D. and BARRETO, M.L., 2003. Aspectos macroepidemiológicos da esquistossomose mansonica: análise da relação da irrigação no perfil espacial da endemia no estado da Bahia, Brasil. Cadernos de Saúde Pública, vol. 19, no. 2, pp. 383-393. http://dx.doi.org/10.1590/S0102-311X2003000200005. PMid:12764454.

MARTINS-MELO, F.R., PINHEIRO, M.C.C., RAMOS JUNIOR, A.N., ALENCAR, C.H., BEZERRA, F.S.M. and HEUKELBACH, J., 2014. Trends in schistosomiasis-related mortality in Brazil, 2000-2011. International Journal for Parasitology, vol. 44, no. 14, pp. 1055-1062. http://dx.doi.org/10.1016/j.ijpara.2014.07.009. PMid:25161102.

MASSARA, C.L., AMARAL, G.L., CALDEIRA, R.L., DRUMMOND, S.C., ENK, M.J. and CARVALHO, O.S., 2008. Esquistossomose em área de ecoturismo do Estado de Minas Gerais, Brasil. Cadernos de Saúde Pública, vol. 24, no. 7, pp. 
1709-1712. http://dx.doi.org/10.1590/S0102-311X2008000700025. PMid:18670694.

MASZLE, D.R., WHITEHEAD, P.G., JOHNSON, R.C. and SPEAR, R.C., 1998. Hydrological studies of schistosomiasis transport in Sichuan Province, China. The Science of the Total Environment, vol.216, no. 3, pp. 193-203. http://dx.doi.org/10.1016/ S0048-9697(98)00152-1. PMid:9646528.

MUNIZ, C., 2007. Levantamento da malacofauna límnica e aspectos ecológicos de focos de esquistossomose em Ana Dias, Vale do Ribeira, SP. São Paulo: Universidade de São Paulo, 164 p. Masters Dissertation.

PARAENSE, W.L., 1970. Planorbídeos hospedeiros intermediários do Schistosoma mansoni. In: A.S. CUNHA, ed. Esquistossomose mansoni: por um grupo de colaboradores especializados. São Paulo: Sarvier/Edups, pp. 13-30.

PASSOS, A.D.C., SILVEIRA, A.C., MADRUGA, J.P., SILVA, J.T.F., PORTO, M.A.S., OLIVEIRA, M.A.H.T., ALVES, M.R.L., SILVA, P.C., AMARAL, R.S. and GUIDA, U., 1998. Vigilância da esquistossomose: diretrizes técnicas. 2th ed. Brasília: Ministério da Saúde, Fundação Nacional de Saúde. 73 p.

PEPE, M.S., 2006. Identificação de populações de Biomphalaria (Gastropoda: Planorbidae) na região sul do Rio Grande do Sul, Brasil. Pelotas: Universidade Federal de Pelotas, 79 p. Masters Dissertation

PIERI, O.S., 2007. Aspectos ecológicos. In: BRASIL. Ministério da Saúde. Vigilancia e controle de moluscos de importância epidemiológica: diretrizes técnicas. 2nd ed. Brasília: Editora do Ministério da Saúde, vol. 3, pp. 37-40.

RAMOS, A.S., PIZA, J.T., PINTO, G.H., TION, T., FLEURY, G.C., MORAIS, L.V.C. and CAMPOS, L.L., 1969. Focos ativos de esquistossomose mansoni no Vale do Ribeira, Estado de São Paulo, Brasil. Cadernos de Saúde Pública, vol. 3, pp. 59-65. http:// dx.doi.org/10.1590/S0034-89101969000100008.
ROLLINSON, D., 2009. A wake up call for urinary schistosomiasis: reconciling research effort with public health importance. Parasitology, vol. 136, no. 12, pp. 1593-1610. http://dx.doi. org/10.1017/S0031182009990552. PMid:19627633.

ROLLINSON, D., KNOPP, S., LEVITZ, S., STOTHARD, J.R., TCHUEM TCHUENTÉ, L.-A., GARBA, A., MOHAMMED, K.A., SCHUR, N., PERSON, B., COLLEY, D.G. and UTZINGER, J., 2013. Time to set the agenda for schistosomiasis elimination. Acta Tropica, vol. 128, no. 2, pp. 423-440. http://dx.doi.org/10.1016/j. actatropica.2012.04.013. PMid:22580511

SINHA, N. and LAMBOURNE, A., 1987. Schistosomiasis control in the southern province of Saudi Arabia. Journal of the Royal Society of Health, vol. 107, no. 3, pp. 79-83, 83. http://dx.doi. org/10.1177/146642408710700302. PMid:3112389.

SOUTHGATE, V.R., 1997. Schistosomiasis in the Senegal River Basin: before and after the construction of the dams at Diama, Senegal and Manantali, Mali and future prospects. Journal of Helminthology, vol. 71, no. 2, pp. 125-132. http://dx.doi. org/10.1017/S0022149X00015790. PMid:9192711.

SOUZA, C.P. and LIMA, L.C., 1997. Moluscos de interesse parasitológico do Brasil. Belo Horizonte: Centro de Pesquisas René Rachou/FIOCRUZ. 76 p.

STEINMANN, P., KEISER, J., BOS, R., TANNER, M. and UTZINGER, J., 2006. Schistosomiasis and water resources development: systematic review, meta-analysis, and estimates of people at risk. The Lancet Infectious Diseases, vol. 6, no. 7, pp. 411-425. http://dx.doi.org/10.1016/S1473-3099(06)70521-7. PMid:16790382.

WORLD HEALTH ORGANIZATION - WHO, 2012 [viewed 11 April 2014]. Schistosomiasis [online]. Genève. Available from: www.who.int/mediacentre/factsheets/fs115/en/index.html

WURAPA, F., BARAKAMFITIYE, D. and MOTT, K.E., 1989. Current of the epidemiology and control of schistosomiasis in Africa. Tropical Medicine and Parasitology, vol. 40, no. 2, pp. 149-152. PMid:2505374. 